\title{
Gut Microbiota-Polyphenol Interactions in Chicken: A Review
}

\author{
Yasir Iqbal ${ }^{1}(\mathbb{D})$, Jeremy J. Cottrell ${ }^{1}\left(\mathbb{D}\right.$, Hafiz A.R. Suleria ${ }^{1}(\mathbb{D})$ and Frank R. Dunshea ${ }^{1,2, *(D)}$ \\ 1 School of Agriculture and Food, Faculty of Veterinary and Agricultural Sciences, \\ The University of Melbourne, Parkville, VIC 3010, Australia; yasir.iqbal@student.unimelb.edu.au (Y.I.); \\ jcottrell@unimelb.edu.au (J.J.C.); hafiz.suleria@unimelb.edu.au (H.A.R.S.) \\ 2 Faculty of Biological Sciences, The University of Leeds, Leeds LS2 9JT, UK \\ * Correspondence: fdunshea@unimelb.edu.au
}

Received: 10 July 2020; Accepted: 9 August 2020; Published: 11 August 2020

check for updates

Simple Summary: Gut microbiota play crucial roles in digestion of feed and absorption of nutrients in fast growing chickens. Gut microbiota affects feed conversion ratio, body weight gain, apparent metabolizable energy, residual feed intake, and time taken to attain the desired weight, which have direct influence on the health and productivity of chickens. A normal gut microbiota is therefore very important for optimum health. Factors like the environment, heat stress, and housing conditions can cause detrimental changes in the gut resulting in poor health of birds and decreased production performance. Polyphenols can be used to improve gut health due to their established health benefits and strong antioxidant potential. The interaction between polyphenols and the gut microbiota further generates active metabolites, which can modulate the composition of the chicken gut microbiota. Because of the specificities of the gut microbiota-polyphenols interactions, current knowledge in this area is presented.

\begin{abstract}
The gastrointestinal tract of the chicken harbors very complex and diverse microbial communities including both beneficial and harmful bacteria. However, a dynamic balance is generally maintained in such a way that beneficial bacteria predominate over harmful ones. Environmental factors can negatively affect this balance, resulting in harmful effects on the gut, declining health, and productivity. This means modulating changes in the chicken gut microbiota is an effective strategy to improve gut health and productivity. One strategy is using modified diets to favor the growth of beneficial bacteria and a key candidate are polyphenols, which have strong antioxidant potential and established health benefits. The gut microbiota-polyphenol interactions are of vital importance in their effects on the gut microbiota modulation because it affects not only the composition of gut bacteria but also improves bioavailability of polyphenols through generation of more bioactive metabolites enhancing their health effects on morphology and composition of the gut microbiota. The object of this review is to improve the understanding of polyphenol interactions with the gut microbiota and highlights their potential role in modulation of the gut microbiota of chicken.
\end{abstract}

Keywords: chicken; gut; microbiota; polyphenols; bioavailability; metabolites; modulation

\section{Introduction}

The gastrointestinal tract of chickens is composed of the crop, gizzard, proventriculus, duodenum, jejunum, ileum, caeca, large intestine (colon) and cloaca [1] all of which contain complex microbial communities with varying populations. These densely populated microbial communities in the gut compartments are collectively called the gut microbiota and includes bacteria, fungi, archaea, protozoa, and viruses, with bacteria the most abundant among all these. Clostridium, Lactobacillus, 
Eubacterium, Bacteroides, Escherichia coli, Prevotella, Selenomonas, Streptococcus, Megasphaera, Fusobacterium, and Bifidobacterium are among the most common bacteria in the chicken gut. The number and type of microbial communities in each section of the gut varies depending upon nutrient flow from the diet, immune responses of the host and the substances produced by this complex microbial system in the gut [2].

Both beneficial bacteria (associated with improved productivity) and harmful bacteria (associated with poor health and diseases) inhabit the gut of healthy birds. However, a dynamic balance is maintained in such a manner that beneficial Gram-positive bacteria generally dominate, constituting more than $85 \%$ of the bacterial population [3]. Some pathogenic bacteria like Clostridium sp. in young birds and E. coli, Campylobacter, and Salmonella in healthy adult birds are also common among other bacteria in the chicken gut [4]. The maintenance of this population in the gut is responsible for the digestion and absorption of nutrients, the development of immunity and disease resistance. A deviation in the normal gut microbiota results in "Dysbiosis" that designates to qualitative or quantitative imbalances of the microbial populations from the normal proportions in the gut. Dysbiosis can cause detrimental changes in the gut affecting the digestion of ingested food, nutrients absorption and mucosal barrier function leading to translocation of infectious bacterial species, and inflammatory response [5]. This can affect feed conversion ratio, productivity, performance, and overall health of poultry birds [6]. A normal gut microbiota is, therefore, very important for optimal health and productivity.

Different factors like environmental conditions, genetic background, age, and stress affect the gut microbiota with the diet being the most influential factor in the development of the gut microbiota and its functionality [7]. The type of feed is crucial in driving the gut microbial ecology in chicken as the undigested and unabsorbed components of feed can serve as substrates for microbial growth in the gut [8,9]. Various feed additives have been used to modulate the gut microbiota of chicken. Previously, antibiotics were used as growth promoters, but consumer awareness about harmful effects of antibiotics coupled with increasing antimicrobial resistance has resulted in increased regulatory oversight and a focus by industry and research to explore alternatives [10]. Feed supplementation with phytochemicals especially polyphenols can serve to fulfill this need as polyphenols and their metabolites can modulate changes in bacterial diversity and population in chicken gut due to their already established health promoting effects [11].

The beneficial properties of polyphenols have been credited to the formation of their biologically active metabolites and their ability to modulate changes in gut microbial populations [11]. The bioavailability of polyphenols is crucial for their effects on gastrointestinal tract and other systems of the body like antioxidant system, cardiovascular, and immune stimulation [12]. The literature regarding bioavailability status of polyphenols reports a low bioavailability, particularly for the proanthocyanidins in chickens [13]. Due to their low absorption, about $90 \%$ of phenolic compounds enter the colon unaltered and interact with colonic bacteria. The gut microbiota-polyphenols interactions play vital roles in modulation of the gut microbiota and not only alter the bacterial composition of gut but also improve the bioavailability of polyphenols by metabolizing them into absorbable metabolites. The altered microbial composition and bacteria-derived metabolites of polyphenols affects the development of the gut and can improve health and productivity of chicken.

\section{Chicken Productivity and Its Relationship with the Gut Microbiota}

Poultry performance may be predicted by recording parameters like feed conversion ratio (FCR), body weight gain (BWG), apparent metabolizable energy (AME), residual feed intake (RFI), and time taken to attain desired weight. Feed conversion ratio can be designated as ratio of ingested feed to gain in body weight and is the most widely used parameter for measuring growth performance. The gut microbiota composition can affect FCR as it plays crucial roles in digesting feed and nutrient absorption. The presence of Campylobacter has been negatively linked with productive performance due to increased FCR [14]. In studies with the cecum, differences among bacterial communities linked to FCR were observed. In most of the studies, Lactobacilli were reported to be linked to higher FCR and 
Faecalibacterium genera were associated with lower FCR. No microbial colonies have been reported to be linked with higher or lower FCR in the jejunum in a study [15]. In contrast, another study linked Lactobacillus, Fructobacillus, Paralactobacillus with high FCR and Leptotrichia, Pediococcus, Rohdococcus, Escherichia coli with low FCR in the jejunum [16].

In the crop, Bacteroidetes, Euryarchaeota, Ruminococcus, and Faecalibacterium bacteria have been reported to be associated with high productivity, whereas, Actinobacteria, Bifidobacterium, and Lactobacillus were found to be associated with low productivity in terms of BWG [17]. Clostridium coccoides were linked with higher BWG, whereas, Enterobacteria, E. coli and Shigella were linked with lower BWG [18]. Some bacterial taxa in the ileum have been identified to be linked with productive performance of chicken. Lactobacillus species have been usually correlated with higher performance and better health [19]. In contrast, two studies have reported Lactobacillus species in the ileum to be associated with low productivity [20].

Prominent variations in microbial communities were observed in the cecum, which harbors the higher diversity of bacterial communities where Lactobacillus salivarius, Lactobacillus crispatus, Lactobacillus aviarius, Clostridium lactatifermentans, some bacteria belonging to Ruminococcaceae family, Akkermansia, Faecalibacterium, and Bacteroides vulgatus were related to improved performance [21], whereas, Escherichia and Shigella strains were correlated with lower fat digestibility and performance in broiler chickens [18]. In some studies with fecal samples, Lactobacillus and Bacteroides were reported to be associated with productive performance [22]. Hence, the composition of the gut microbiota can affect the productive performance of the chicken (Table 1). However, the relationship between the gut microbiota composition and productive performance of chickens has not yet been fully elucidated. Some authors have reported that high feed efficiency is associated with less diverse gut microbiota in chicken [20], while others have linked higher bacterial communities' complexity and richness with better feed efficiency [21].

\section{Gut Microbiota-Polyphenols Interaction and Effects on Chicken Gut Microbiota}

Gut microbiota-polyphenols interaction is a two-way process in which the gut microbes metabolize polyphenols into simpler metabolites whereas polyphenols affect the growth and population of gut microbes by interfering with their metabolic activities [23] (Table 2). The bioavailability of polyphenols is also increased due their transformation into absorbable metabolites [11]. Particularly, Lactobacilli bacteria are capable of metabolizing polyphenols producing energy for use by cells and simpler compounds that can interfere with metabolic activities of gut bacteria. Lactobacillus acidophilus can deglucosylate plant glycosides and produce aglycones [24] and some microbial taxa (Lactobacillus delbrueckii and Eubacterium ramulus) can use these aglycones as nutritional substrates [25]. Others (B. ovatus, Veillonella sp. and Ruminococcus productus) can further metabolize aglycones via ring opening, breakdown of lactone, decarboxylation, dehydroxylation, demethylation, reduction, and isomerization [26].

Enzymatic action of colonic bacteria breaks down the basic structures of unabsorbed polyphenols and increases their bioavailability by transforming them into low molecular weight metabolites of varying bioactive potentials $[27,28]$. These low molecular weight polyphenol metabolites can persist in the plasma and can exhibit improved health promoting effects. While the greatest numbers of bacterial species inhabit the colon, a few of them (E. coli, Lactobacillus sp., Bifidobacterium sp., Bacteroides sp., and Eubacterium sp.) are known for metabolisms of polyphenols with their metabolic pathways [29]. 
Table 1. Correlation of microbial taxa with productive performance of chicken.

\begin{tabular}{|c|c|c|c|c|}
\hline \multirow{2}{*}{ Sample } & \multirow{2}{*}{ Performance Parameter } & \multicolumn{2}{|c|}{ Microbial Taxa Identified } & \multirow{2}{*}{ References } \\
\hline & & Higher Productive Performance & Lower Productive Performance & \\
\hline \multirow{2}{*}{ Crop } & BW & $\begin{array}{l}\text { Faecalibacterium, Euryarchaeota, } \\
\text { Bacteroidetes, Ruminococcus }\end{array}$ & Bifidobacterium, Actinobacteria, Lactobacillus & [17] \\
\hline & BW & C. coccoides & Shigella, E. coli, Enterobacteria & [18] \\
\hline Duodenum & RFI & Lactobacilli & Bacteroides & [21] \\
\hline \multirow{2}{*}{ Jejunum } & FCR & No difference & No difference & [15] \\
\hline & FCR & Lactobacillus, Fructobacillus, Paralactobacillus & Leptotrichia, Pediococcus, Rohdococcus, Escherichia coli & [16] \\
\hline \multirow{4}{*}{ Ileum } & BW & $\begin{array}{c}\text { Spirochaetes, Euryarchaeota, } \\
\text { Bifidobacterium, Methanobrevibacter }\end{array}$ & Akkermansia, Streptococcus & [17] \\
\hline & BW & Bacteroides & - & [18] \\
\hline & RFI, TFI, TBWG & Enterobacteriaceae & Turicibacter, Lactobacillus and Ruminococcus & [20] \\
\hline & FCR & $\begin{array}{c}\text { Enterococcus, Clostridium, Pseudanabaena, Bacillus, } \\
\text { Mannheimia, Granulicatella }\end{array}$ & Halochromatium & [16] \\
\hline \multirow{3}{*}{ Ileum-Cecum } & RFI & Turicibacter, Coprococcus and Ruminococcus, & Proteobacteria and Clostridiales & [30] \\
\hline & BW & Lactobacillus, Actinobacteria, Firmicutes and Tenericutes & Clostridium, Firmicutes, Bacteroidetes and Proteobacteria & [31] \\
\hline & BW & Butyricimonas, Bilophila, Faecalibacterium and Bacteroides & $\begin{array}{l}\text { Enterococcus, Coprococcus, Anaerotruncus, Coprobacillus, } \\
\text { Bacteroides, Clostridium, Streptococcus, Lactobacillus, } \\
\text { Ruminococcus, Staphylococcus and Enterobacteriaceae }\end{array}$ & [32] \\
\hline \multirow{4}{*}{ Cecum } & FCR & B. fragilis & Ruminococcus, Clostridiales and L.crispatus & [15] \\
\hline & RFI & $\begin{array}{c}\text { Prochlorococcus marinus, Akkermansia, L. reuteri, } L . \\
\text { delbrueckii, Prevotella, B. coprophilus and } \\
\text { L. Veillonella dispar }\end{array}$ & $\begin{array}{c}\text { Parabacteroides distasonis, Helicobacter, F. prausnitzii, } \\
\text { Thermobispora bispora }\end{array}$ & [21] \\
\hline & FCR & R. torques, F. prausnitzii and C. lactatifermentans & B. vulgatus and Alistipes finegoldii & [33] \\
\hline & BW & Lactobacillus & Escherichia, Campylobacter and Shigella & {$[14,18]$} \\
\hline \multirow{4}{*}{ Feces } & RFI & Helicobacter & Lactobacillus and Clostridium & [21] \\
\hline & TBWG, RFI, TFI & Enterobacteriaceae and Lactobacillaceae & Acinetobacter, Comamonadaceae and Moraxellaceae, & [34] \\
\hline & FCR & $\begin{array}{c}\text { Synergistaceae, Victivallaceae, Prevotellaceae, Rikenellaceae, } \\
\text { Enterobacteriaceae and Ruminococcaceae }\end{array}$ & $\begin{array}{c}\text { Xanthomonadaceae, Incertae, Vibrionaceae, } \\
\text { Fusobacteriaceae, Campylobacteraceae, Rhizobiaceae, } \\
\text { Flavobacteriaceae, Comamonadaceae }\end{array}$ & [22] \\
\hline & TBWG, RFI, TFI & L. salivarius, Anaerobacterium, L. crispatus & Klebsiella & [35] \\
\hline
\end{tabular}

AME: apparent metabolizable energy; FCR: feed conversion ratio; BW: body weight; RFI: residual feed intake; TFI: total feed intake; TBWG: total body weight gain. 
The microbial derived metabolites and primary polyphenolic compounds can affect microbial composition of the gut and signaling pathways [35]. The strong antioxidant potential of polyphenols provides protection to the epithelial wall of the colon and mucosa and shapes the gastrointestinal environment for the growth of microbial communities in the colon by exerting prebiotic effect and antimicrobial action. Polyphenols affect epigenetic changes in intestinal tissues and modulate intracellular receptors and signaling molecules [36]. These phenolic compounds also affect the intestinal detoxification systems and exert antioxidant action on pre-colon epithelial cells [36]. Polyphenols provide protection to epithelial cells and prevent inflammation in the intestines resulting in improved gut barrier function [37].

Polyphenols suppress pathogenic bacteria on one hand while supporting beneficial bacteria by acting as prebiotics on the other hand. The antimicrobial properties of polyphenols are of prime importance and prevent the formation of biofilms in the gut by suppressing the growth of harmful bacterial species [26]. Polyphenols like quercetin, hydroxytyrosol, resveratrol, and phenolic acids exhibit antimicrobial properties against various pathogenic bacteria including Helicobacter pylori and Salmonella and are known to inhibit various pathogenic microbes. Resveratrol can suppress the population of Escherichia coli and can ameliorate the impact of heat stress in broilers [38]. Whereas, quercetin can suppress $S$. enteritidis and can affect pro-inflammatory gene expression [39]. The antimicrobial action of these compounds is accomplished by various mechanisms that include direct inhibition of certain bacterial species, reduction of adhesion ability of pathogenic bacteria, or disruption of ionic fluxes at the cell membrane [40]. The concentration of phenolic compounds in feed, selectivity of their antimicrobial action, and bacterial resistance to these natural antimicrobials affect the susceptibility of bacteria [40]. Improved nutrient utilization and increased bird performance have been linked with polyphenols due to inhibition of harmful bacteria (E. coli, Clostridium) adhesion, thereby preventing gut infections [25].

Polyphenols possess prebiotic action and support growth of selective bacteria by acting as a source of nutrient supply [41,42]. Due to "prebiotic-like" effect, polyphenols can enhance multiplication of favorable microbes such as the Lactobacilli and Bifidobacteria populations [43]. Ingestion of different polyphenols is linked to varying ratios of gut bacteria, Bacteroides and Firmicutes, favoring the growth of Bacteroides that possess a higher number of glycan-degrading enzymes. Feed supplemented with polyphenol-rich grapes enhanced Enterococcus population while decreasing Clostridium levels in chickens [25]. Feeding cranberry extract containing anthocyanins, flavanols, flavonols, and phenolic acids markedly reduced Enterococcus species population in broilers [44]. Polyphenols rich green tea and mulberry leaves are among the most widely-used plant components in poultry production [45] and are reported for selective inhibition of some disease-causing bacterial strains without impacting commensal bacterial communities. Sugarcane-derived polyphenol mix (Polygain) can improve meat stability in chicken [46]. Grape polyphenol extract can also improve oxidative stability of meat by favoring the growth of beneficial bacterial communities (Lactobaccilli and Bifidobacteria) in intestines [47]. Addition of polyphenols-rich powdered mulberry leaves in feed of chicken resulted in increased population of Prevotella, Megamonas, and Bacteroides in the gut of chicken. These reports are indicative of the fact that powdered mulberry leaves and green tea (rich in polyphenols) possess potential to influence gut microbiota of chicken [48].

Polyphenol rich blueberry byproducts also favored population of certain bacterial species including Bacteroidetes in ceca and cloaca of birds [49], whereas cranberry pomace fractions caused inhibition of AMR Salmonella serovars by interfering with cell metabolic activities, nutrient utilization, and virulence capacity of Salmonella enteritidis in broilers [50]. Berry pomaces suppress C. perfringens pathogenesis in broilers and promotes gut health [51]. Wine polyphenols can promote Bifidobacteria and Lactobacilli growth, while inhibiting Clostridia [25].

Morphological traits (length of villi, crypt depth, and height) are indicators of gut health. Lengthening of villi affects digestion, improves absorption of nutrients, and promotes BWG. Therefore, alterations in intestinal morphology can affect nutrient absorption and animal performance. Polyphenols may exert effects on gut morphology. Feeding broilers with essential oils containing 
polyphenols caused an increase in villus height in the duodenal section of the gut [52]. This report was also supported by another study that concluded that hesperidin, genistein, and some flavonoids from Ginkgo biloba leaves increased absorptive surfaces of the small intestine by modifying its length, crypt depth, and villus width in broilers with lipopolysaccharide stress [53]. Chickens fed with diet supplemented with vitamin $C$ and polyphenols presented an increase in length of the intestinal villi [54].

Table 2. Gut Microbiota-polyphenols interaction and its effects on the gut.

\begin{tabular}{|c|c|c|c|c|}
\hline Polyphenol & Bacteria Involved & Mechanism & Effect & References \\
\hline Curcumin & Firmicutes, Enterobacteriaceae & Antibacterial activity & $\begin{array}{l}\text { Improved antioxidant } \\
\text { potential/Modulation of } \\
\text { gut microbiota }\end{array}$ & [55] \\
\hline Naringenin/Hesperetin & $\begin{array}{l}\text { Escherichia coli, } \\
\text { Helicobacter pylori, } \\
\text { Salmonella aureus }\end{array}$ & Antibacterial activity & $\begin{array}{l}\text { Affected upper part of gut, } \\
\text { altered gut bacteria patterns }\end{array}$ & [41] \\
\hline Quercetin & Bifidobacteria and coliforms & Antibacterial activity & $\begin{array}{l}\text { Modulation of cecal } \\
\text { bacteria population }\end{array}$ & {$[56]$} \\
\hline Soybean polyphenols & $\begin{array}{l}\text { L. delbrueckii, L intermedius, } L \text {. } \\
\text { johnsonii, L. panis, L. reuteri }\end{array}$ & Prebiotic effect & Modulation of gut microbiota & [57] \\
\hline Resveratrol & E. coli & Antibacterial activity & $\begin{array}{l}\text { Ameliorated dysbiosis caused } \\
\text { by heat stress }\end{array}$ & [38] \\
\hline
\end{tabular}

\section{Class Specific Polyphenols-Gut Microbiota Interactions and Their Role in Modulation of Chicken Gut Microbiota}

The microbial transformations can differ depending on the type of polyphenolic structures (flavonoids or nonflavonoids), degree of polymerization and spatial configuration. Therefore, members of different subgroups and categories are metabolized through different pathways and result in different metabolic products causing differential effects on the gut microbiota (Tables 2 and 3 ).

\subsection{Flavonoids-Gut Microbiota Interactions and Their Role}

Flavonoids (flavonols, flavanones, flavanols, isoflavones, flavones, and anthocyanins) have a backbone consisting of benzene rings ( $\mathrm{A}$ and $\mathrm{B}$ ) joined by pyrone $\mathrm{C}$-ring [58]. Bacteria in the gut can cause cleavage of the $\mathrm{C}$-ring from different positions, thus generating various simple phenolic moieties (Table 3). The position and pattern of B-ring hydroxylation influences the types of generated phenolic metabolites. Following C-ring-cleavage, flavonoids undergo further metabolism through demethylation and dehydroxylation reactions by the gut bacteria [59]. Different stains of Lactobacilli bacteria take part in the metabolism of flavonoids in the chicken gut [59].

Flavonoids and their microbiota derived metabolites show antimicrobial potential and have the ability to suppress pathogenic microbes [60]. Numerous in vitro studies showed that flavonoids from grape by-products can suppress certain bacteria such as S. aureus, E. coli, C. albicans, and Campylobacter, and can modulate composition of gut microbiota in chicken and improve their immunity and health [61,62]. Besides improving immunity, they affect gut functionality and promote gut morphology [61,62]. Genistein and hesperidin are known to regulate mucosal and cellular immunity [63]. Flavonoids [54] and flavonoids-rich fermented Ginkgo biloba leaves [64] have already been reported to promote intestinal morphology and absorption of nutrients in broilers. Hence, flavonoids can improve the gut morphometric index through the modulation of gut microbiota, providing protection against oxidative stress to epithelial cells [65]. However, the exact mechanisms by which flavonoids affect the intestinal architecture are yet to be described. 


\subsubsection{Flavonols}

Flavonols (kaempferol, quercetin, rutin, andmyricetin) are the flavonoids that have a 3-hydroxyflavone framework. These flavonoids are broken down by gut bacteria to produce simpler metabolites after C-ring cleavage. Gut microbes involved in these transformations include Bacteroides distasonis, Bacteroides ovatus, Eubacterium ramulus, Enterococcus casseliflavus, and Bacteroides uniformis [66]. Quercetin is the most studied member of this subgroup that is degraded by various bacteria including Lactobacilli [59].

Flavonols exhibit antimicrobial activities and can inhibit the growth of selective bacterial species. Among the flavonols, quercetin was reported to cause effective inhibition of bacteria like Pseudomonas aeruginosa, Salmonella enterica serotype Typhimurium, Staphylococcus aureus, and Escherichia coli in broilers [67]. Quercetin supplementation can also enhance performance efficiency in birds because it has the ability to modulate the intestinal architecture of chicken [56]. Rutin supplementation can improve FCR and promote BWG in broilers due to its favorable effects on gut morphology and small intestine functionality [25]. However, an in vitro study involving quercetin, myricetin, galangin, kaempferol, and fisetin reported only weak antimicrobial action of these flavonols against B. adolescentis, except galangin that caused effective inhibition (30 to 70\%) of B. adolescentis [68].

Table 3. Main gut microbiota transformed flavonoid metabolites and the bacteria involved.

\begin{tabular}{|c|c|c|c|c|}
\hline Subclass & Compounds & Metabolites Identified & Bacteria Involved & References \\
\hline \multirow[b]{2}{*}{ Flavonols } & Rutin & \multirow{2}{*}{ Quercetin } & Lactobacilli & [59] \\
\hline & Quercetin & & Lactobacilli & [59] \\
\hline \multirow{3}{*}{ Isoflavones } & Daidzein & Equol & & [69] \\
\hline & & O-demethylangolensin & & {$[70]$} \\
\hline & Genistein & $6^{\prime}$-hydroxy-O-desmethylangolensin & & \\
\hline \multirow{5}{*}{ Flavanols } & Epicatechin & 3-(3,4-dihydroxyphenyl)propionic acid & \multirow{5}{*}{$\begin{array}{l}\text { Bifidobacterium spp., } \\
\text { Clostridium coccoides }\end{array}$} & \multirow{5}{*}{ [71] } \\
\hline & & 5-(3,4-dihydroxyphenyl)valeric acid, & & \\
\hline & & 5 - $\left(3^{\prime}, 4^{\prime}\right.$-dihydroxyphenyl)- $\gamma$-valerolactone & & \\
\hline & & 5- $\left(3^{\prime}, 5^{\prime}\right.$-dihydroxyphenyl)- $\gamma$-valerolactone & & \\
\hline & Epigallocatechin & 5-( $\left(3^{\prime}, 4^{\prime}\right.$-dihydroxyphenyl)- $\gamma$-valerolactone & & \\
\hline Anthocyanins & $\begin{array}{c}\text { Peonidin } \\
\text { Malvidin Pelargonidin } \\
\text { Cyanidin }\end{array}$ & $\begin{array}{c}\text { 3-methoxy4-hydroxybenzoic acid } \\
\text { 3,4-dimethoxybenzoic acid } \\
\text { 4-hydroxybenzoic acid } \\
\text { 3,4-dihydroxybenzoic acid }\end{array}$ & $\begin{array}{c}\text { Lactobacillus plantarum, } \\
\text { Bifidobacterium lactis BB-12, } \\
\text { Lactobacillus acidophilus LA-5, } \\
\text { Lactobacillus casei }\end{array}$ & [72] \\
\hline
\end{tabular}

\subsubsection{Flavanones}

Flavanones (hesperetin, naringenin) are those flavonoids that share a 2,3-dihydro-2phenylchromen-4-one backbone. These flavonoids appear to be more bioavailable as they are resistant to degradation by some colonic microbes. Deglycosylation and further metabolism of flavanones by gut bacteria appear to be similar to that of flavonols. Bacterial enzymes release the aglycones from flavanones like hesperidin and narirutin in colon. These aglycones are further transformed into phenolic acid moieties. Gut microbes such as E. ramulus and Clostridium species are capable of carrying out such colonic transformations [66]. Hydroxylated forms of phenylpropionic acid including 3-(3-hydroxy-4- methoxyphenyl)-propionic acid (dihydroisoferral acid) are noticed as colonic metabolites of hesperidin [73].

Prebiotic-like effects of hesperidin have been reported in the gastrointestinal tract of poultry [53]. Supplementation of feed with hesperidin $(20 \mathrm{mg} / \mathrm{kg}$ diet $)$ could improve gut health and boost immunity in poultry [53]. Glycosylated hesperidin also showed antibacterial action against pathogens like Aeromonas hydrophila. Sulphonated hesperidin, one of the plasma metabolites of hesperidin, can inhibit Neisseria gonorrhoeae and Chlamydia trachomatis [42]. Hesperetin aglycon (a citrus flavanone) can also inhibit Helicobacter pylori and vancomycin-intermediate Staphylococcus aureus (VISA) [74,75]. Naringenin favored the population of Lactobacillus rhamnosus as well as some disease-causing bacteria including 
Escherichia coli, Staphylococcus aureus, and Salmonella thypi [76]. The flavanones naringin and hesperidin also improved the FCR in broilers and enhanced the quality and oxidative stability of meat $[77,78]$.

\subsubsection{Isoflavones}

Isoflavones have planar basic ring system and have estrogenic properties. Almost all isoflavones are found in the glucosidal form and have very low absorption due to their high molecular weight and polarity. Their bioavailability depends on conversion of the glucosides to bioactive aglycones in the small intestine by enzymatic action of gut bacteria. Isoflavones are transformed into equol that is recognized for its positive health effects as compared to the primary isoflavones [79]. A study reported the conversion of isoflavone daidzein to equol in laying hens [69]. Gut microbiota of broilers can transform isoflavone glucosides into aglycones [57]. However, the metabolic pathway and bacteria involved in the biotransformation of isoflavones in poultry gut are yet to be described [69].

Isoflavones do affect the microbiota composition as some members of this subclass like daidzein and genistein have been reported to cause inhibition of certain gut bacteria [80]. They showed antimicrobial action against multiple resistant S. aureus (MRSA) strains [80]. Mechanism of their antimicrobial action could be due to the inhibition of bacterial topoisomerase IV [81]. Isoflavones can also favor certain bacteria in the chicken gut. Feeding of isoflavones-rich soybean meal increased the population of L. delbrueckii, L intermedius, L. johnsonii, L. panis, and L. reuteri in broilers [57].

\subsubsection{Flavanols}

Flavanols comprise a complex subgroup of flavonoids containing simple flavanols (catechins, epicatechins, gallocatechins, epigallocatechins, and their gallate esters) and the corresponding polymeric structures. Bioavailability of flavanols is determined by their degree of polymerization and galloylation. Compounds having polymerization degree $>3$ pass to the colon unabsorbed where they are broken down [71]. Colonic bacteria break down the gallate esters. Epicatechin gallate and epigallocatechin gallate are transformed into aglycones that are further metabolized to pyrogallol [71]. The aglycones undergo C-ring cleavage and produce diphenylpropan-2-diol that is transformed into 5-( $3^{\prime}, 4^{\prime}$-dihydroxyphenyl)- $\gamma$-valerolactone. Further metabolism yields $\mathrm{OH}$-phenylpropionic and hydroxybenzoic acid moieties [71]. Hence, bioavailability and biological actions of flavanols are affected by the gut microbiota [82]. Clostridium (Clostridium coccoides) and Bifidobacterium (Bifidobacterium infantis) are considered responsible for these transformations [82].

Flavanols affect the microbial composition and their catabolic activities in the gut as some flavanol metabolites were reported to favor Lactobacillus/Enterococcus while causing a decrease in the population of C. histolyticum [43]. Catechin and its metabolites can inhibit E. coli, Clostridium difficile and Salmonella [83] without affecting Lactobacillus spp. [43]. High doses of flavanols have been linked with increased populations of Bifidobacterium in the colon. Polyphenon G powder (tea-derived catechins formulation) significantly increased Lactobacillus while markedly suppressing Enterobacteriaceae in broilers [84]. Catechins and epigallocatechins from tea also promote bacterial adhesion of Lactobacillus rhamnosus that supports mucosal defense [85]. Epigallocatechin shows antibacterial action against Staphylococcus and inhibits biofilm formations [86]. Epigallocatechin can also kill other bacteria including Streptococcus pyogenes [87], Bacillus spp. and Clostridium spp. [88], Salmonella typhi [89], and entero-hemorrhagic E. coli [90].

\subsubsection{Anthocyanins}

The anthocyanins, which include pelargonidin, cyanidin, and malvidin exhibit very low absorption as only a small fraction of these compounds is hydrolyzed and transformed to absorbable metabolites. Hence, large quantities of ingested anthocyanins enter the colon [91] and interact with colonic microbiota [92]. Acylated forms of anthocyanins are also catabolized by gut bacteria. Gut bacteria break down the glycosidic bonds in anthocyanidins and open up the heterocycles. Cleavage of 3-glycosidic linkage by gut bacteria was confirmed by Keppler and Humpf [92]. Bacteria involved in 
breakdown of anthocyanins are Bifidobacterium lactis, Lactobacillus plantarum, Lactobacillus acidophilus, and Lactobacillus casei [72]. Anthocyanins are first deglycosylated and then degraded into simpler phenolic acids by colonic microflora. For example, malvidin-3-glucoside is transformed into syringic, gallic, and p-coumaric acids by fecal bacteria. Protocatechuic acid is identified as the main gut microbiota derived metabolite of anthocyanidin. Other microbial derived metabolites of anthocyanins are phloroglucinol and vanillic [92,93].

Anthocyanins and their metabolites can regulate changes in the gastrointestinal tract by favoring the growth of beneficial bacteria like Lactobacillus and Enterococcus [51]. They can ameliorate heat stress in chickens and can serve as feed additives in poultry production. Feeding of anthocyanin-rich cranberry extract containing 40,80, or $160 \mathrm{mg} / \mathrm{kg}$ anthocyanins resulted in superior FCR and improved BWG in broilers [44]. Anthocyanins also improve organ functionality and reduce pathogenic bacteria in the poultry gut. They favor Bifidobacterium spp., Enterococcus spp., and Lactobacillus spp., and can result in favorable microbiota modulation [51]. Anthocyanins can also suppress pathogenic bacteria. Birds fed with high concentrations of cranberry extract containing $160 \mathrm{mg} / \mathrm{kg}$ of anthocyanins decreased Enterococcus spp. population in caeca and cloaca [94].

\subsubsection{Flavones}

Flavones (luteolin and apigenin) occur in the glycosylated form in nature. These flavonoids are transformed into aglycones by some Lactobacillus bacteria including Lactobacillus agilis in the chicken gut [59]. Once the glucosides are hydrolyzed in the intestines, the unabsorbed aglycones undergo further degradation through C-ring cleavage by colonic bacteria and are converted to absorbable metabolites [59].

Flavones and their metabolites can affect gut health in poultry. Alfalfa flavones enhanced growth efficiency in chickens [95]. Flavones have shown antibacterial potential against various microbes. Particularly, luteolin exhibited antibacterial potency against amoxicillin resistant E. coli [96]. It also suppressed S. aureus, E. coli, B. subtilis, and P. fluorescens [97]. Luteolin and its 4'-O-glucoside are bactericidal to $E$. coli at minimum inhibitory concentration of $1.0 \times 10^{-1} \mathrm{mg} / \mathrm{mL}$ and $S$. aureus at $5.0 \times 10^{-2}[98]$.

\subsection{Non-Flavonoids-Gut Microbiota Interactions and Their Role}

Non-flavonoids comprise a complex and heterogeneous group of polyphenols ranging from the simplest hydroxybenzoic acids and hydroxycinnamic acids to complex stilbenes, lignans, and tannins [37]. They vary in complexity of structure among different subclasses and show different levels of bioavailability and their metabolism in the gut varies depending on the level of complexity of their structures among different subclasses [37] (Table 4).

\subsubsection{Phenolic Acids}

Phenolic acids are the compounds having both carboxylic acid (-COOH) and hydroxyl (-OH) groups attached to the benzene ring. They can be divided into hydroxy benzoic acids and hydroxy cinnamic acids [37]. The general structure of hydroxy benzoic acids can be abbreviated as $\mathrm{C}_{6}-\mathrm{C}_{1}$ whereas hydroxycinnamic acids are the derivatives of cinnamic acids and belong to phenylpropanoids having a $\mathrm{C}_{6}-\mathrm{C}_{3}$ backbone [99]. Protocatechuic acid, vanillic acid, syringic acid, and $p$-hydroxybenzoic acid are the four predominant members of hydroxy benzoic acids, whereas caffeic acid, $p$-coumaric acid, ferulic acid, and sinapic acid belong to hydrocinnamic acids [37].

A general trend in the metabolism of phenolic acids is that the free acid is released by bacterial esterases and double bond is then reduced to produce phenylpropionic acid and further decarboxylated to yield phenylacetic acids. Reduction follows dehydroxylation resulting in the removal of hydroxyl at C4-position of hydroxycinnamic acid residue. Gallic acid (3,4,5-trihydroxybenzoic acid) generates pyrogallol (1,2,3-trihydroxyphenol), and protocatechuic acid (3,4-dihydroxybenzoic) is converted to catechol (1,2-dihydroxyphenol). Similarly, vanillic acid (3-methoxy-4-hydroxybenzoic acid) is 
transformed into O-methylcatechol [100]. Caffeic acid produces 3-hydroxyphenylpropionic acid and benzoic acid. Both these metabolites are also generated from chlorogenic and caftaric acid, suggesting that esterification does not affect metabolism of caffeic acid by gut microbiota. Bifidobacterium and Lactobacillus seem to be involved in transformation of chlorogenic acid [101]. Microbiota derived metabolites of ferulic acid include vanillin and 3-(4-hydroxyphenyl)-propionic acid. In vivo phase II metabolism of microbial metabolites of caffeic acid generates glycynated metabolites that includes hippuric acid and 3-hydroxyhippuric acid [66].

Phenolic acids and their microbial metabolites affect intestinal bacteria composition and their metabolic activity [102]. 3-O-methylgallic acid, caffeic acid, and gallic acid can decrease the population of pathogens (C. perfrigens, $C$. difficile, and Bacteroides spp.) without affecting commensal anaerobic bacteria (Bifidobacterium spp.) and probiotic bacteria (Lactobacillus spp.) [103]. Gallic acid prevents the formation of biofilms as it reduced biofilm formation activity of E. coli, P. aeruginosa, S. aureus, and L. monocytogenes by $>70 \%$ [104]. It further inhibits the growth of Streptococcus mutans and affects the adhesion properties of S. aureus [104]. Furthermore, gallic acid supplementation can affect the morphology of the gut and enhance the absorption of nutrients by improving the villus height to crypt depth ratio in broilers [41].

Hydroxycinnamic acids like chlorogenic acid, $p$-coumaric acid, coumaric acid, and caffeic acid affected Escherichia coli, Bacillus cereus, and Staphylococcus aureus [105]. Caffeic acid has been reported as the strongest inhibitor of the growth of E. coli, Salmonella, Pseudomonas, Clostridium, and Bacteroides [103].

Table 4. Gut microbiota derived nonflavonoids metabolites and bacteria involved.

\begin{tabular}{|c|c|c|c|c|}
\hline Subclass & Compounds & Metabolites Identified & Bacteria Involved & References \\
\hline Phenolic acids & $\begin{array}{l}\text { Caffeic acid, } \\
\text { Ferulic acid }\end{array}$ & $\begin{array}{c}\text { Hydroxyphenyl-ethanol } \\
\text { 3-(4-hydroxyphenyl)-propionic acid } \\
\text { 3-(4-hydroxyphenyl)-propionic acid } \\
\text { Phenylacetic acid } \\
\text { 3-(3-hydroxyphenyl)-propionic acid } \\
\text { 3-(3,4-dihydroxyphenyl)-propionic acid } \\
\text { Benzoic acid }\end{array}$ & $\begin{array}{l}\text { Lactobacillus gasseri, } \\
\text { Bifidobacterium lactis, } \\
\text { Escherichia coli }\end{array}$ & [106] \\
\hline Lignans & & $\begin{array}{c}\text { Enterodiol } \\
\text { Enterolactone }\end{array}$ & & [108] \\
\hline
\end{tabular}

\subsubsection{Tannins}

Despite their complex structure, tannins are metabolized by gut microbiota. Gut bacteria have the ability to hydrolyze ester bonds in tannins through tannin acyl hydrolase activity [109]. Hydrolysis of tannin-O-glycosides produces gallic acid residues from gallotannins and ellagic acid from ellagitannins. Ellagic acid dehydroxylation produces nasutins in which two hydroxyl groups are removed [109]. Ellagic acid degradation also takes place by lactone-ring cleavage and decarboxylation. Ellagic acid is transformed into urolithins in the mammalian gut. However, the transformation of ellagic acid into urolithins in the chicken gut has not been reported [110].

Tannins caused an increase in Bacteroidetes and Firmicutes in caecal microbial communities of chickens [111]. Tannins can induce iron-poor conditions and support the growth of Lactobacillus bacteria, as these bacteria do not require iron for their growth [112]. Dietary tannin supplementation has also been associated with a reduction in the population of Bacteroides resulting in decreased acetate and propionate production. However, increased population of Clostridiales, specifically the members of Ruminococcaceae, compensates for this decrease by producing butyrate [113]. An overall rise in short chain fatty acid production in poultry has been associated with tannic acid supplementation [114]. With regards to morphology, sorghum tannins did not show any adverse effects on intestinal morphology in chickens or laying hens [115]. However, faba bean tannins have been reported to cause atrophy and shortening of villi in chicken [116]. 


\subsubsection{Lignans}

Lignans are polyphenols with a 1,4-diarylbutane structure and contain diphenolic compounds. During metabolism, plant lignans undergo glucuronidation and to a lesser extent sulphation [117]. Biological actions of lignans depend on their conversion to their phytoestrogenic forms, i.e., enterolactone and enterodiol [108]. These enterolignans are produced by gut microbiota. The presence of microorganisms capable of converting lignans into enterolignans is important for their health benefits [117]. Lignans metabolism by gut microbiota involves demethylation, reduction, dehydroxylation, and lactonization [108], and phytoestrogens are produced by Eubacterium and Peptostreptococcus bacteria. Pinoresinol and lariciresinol undergo benzyl ether reduction, guaiacol demethylation, catechol dihydroxylation, and diol lactonization reactions and are transformed via various intermediary compounds into enterodiol and enterolactone from dietary lignans [118]. However, it is difficult to predict a definite relation between lignans and gut microbiota due to lack of scientific reports in this area.

\subsubsection{Stilbenes}

Stilbenes have a C6-C2-C6 structure and can be metabolized by gut bacteria. Trans-resveratrol is the most studied stilbenoid due to its well-known health-effects [119]. Gut microbes are able of metabolize resveratrol. Resveratrol and its precursors including piceid undergo microbial metabolism in the gut and can produce bioactive metabolites like dihydroresveratrol. Little is known about the fate of resveratrol in the chicken gut due to scarcity of scientific literature. Resveratrol has very low bioavailability [13]. Therefore, resveratrol can play a role in modulation of the gut microbiota of chicken due to its antimicrobial potential. Resveratrol exhibits antibacterial activity against Salmonella enterica, Enterococcus faecalis, and Escherichia coli [120]. Resveratrol also suppresses the growth of E. coli while causing a significant increase in Lactobacilli and bifidobacteria [38]. Another study supported these results and reported an increase in Lactobacilli and bifidobacteria while decreasing Clostridium perfringens in the chicken gut [121]. Resveratrol also improved villus height to crypt depth ratio by increasing villus height and lowering the crypt depth [38]. Hence, resveratrol can improve immunity, gut health, and growth performance by affecting gut permeability and composition of microbiota in chickens [122].

\section{Conclusions}

A healthy gut system is of prime importance in poultry production. Detrimental changes induce dysbiosis in the gut, which results in poor performance and a decline in overall health of chickens. Polyphenols supplementation can improve gut health and productivity of the chicken. Health promoting properties of these phenolic compounds are attributed to their effects on gut microbiota. The gut microbiota-polyphenol interactions are a two-way process in which gut microbes transform polyphenols into their bioactive metabolites having improved bioavailability and health effects, whereas polyphenols and their gut microbiota derived metabolites can support growth of beneficial bacteria and inhibit pathogens. Study of gut microbiota-polyphenols interactions is an emerging field of interest due to its importance in gut health and modulatory effects. Further research should, therefore, be focused on understanding gut microbiota-polyphenols interaction, their effects on gut microbiota, meat quality, and overall health of poultry by conducting feeding trials using different plant sources containing polyphenols to develop an optimum feeding strategy for sustainable poultry production.

Author Contributions: Conceptualization, Y.I., H.A.R.S., and F.R.D.; methodology, Y.I., H.A.R.S. and F.R.D.; resources, H.A.R.S. and F.R.D.; writing一original draft preparation, Y.I.; writing-review and editing, Y.I., H.A.R.S., J.J.C. and F.R.D.; supervision, H.A.R.S., J.J.C. and F.R.D.; project administration, Y.I., H.A.R.S. and F.R.D.; funding acquisition, H.A.R.S. and F.R.D. All authors have read and agreed to the published version of the manuscript.

Funding: This research received no external funding. 
Acknowledgments: We would like to thank Kawther Ghozlan, Akhtar Ali, Chao Ma, and Yasmeen Mohammad Bashmil from the School of Agriculture and Food, Faculty of Veterinary and Agricultural Sciences, The University of Melbourne for their support. We are also thankful to the Higher Education Commission of Pakistan and The University of Melbourne, Australia for providing support.

Conflicts of Interest: The authors declare no conflicts of interest.

\section{References}

1. Yeoman, C.J.; Chia, N.; Jeraldo, P.; Sipos, M.; Goldenfeld, N.D.; White, B.A. The microbiome of the chicken gastrointestinal tract. Anim. Healths Res. Rev. 2012, 13, 89-99. [CrossRef] [PubMed]

2. Oviedo-Rondon, E.O.; Hume, M.E.; Hernandez, C.; Clemente-Hernandez, S. Intestinal microbial ecology of broilers vaccinated and challenged with mixed Eimeria species, and supplemented with essential oil blends. Poult. Sci. 2006, 85, 854-860. [CrossRef] [PubMed]

3. Sugiharto, S. Role of nutraceuticals in gut health and growth performance of poultry. J. Saudi Soc. Agric. Sci. 2016, 15, 99-111. [CrossRef]

4. Choct, M. Managing gut health through nutrition. Br. Poult. Sci. 2009, 50, 9-15. [CrossRef] [PubMed]

5. Teirlynck, E.; Gussem, M.D.E.; Dewulf, J.; Haesebrouck, F.; Ducatelle, R.; Van Immerseel, F. Morphometric evaluation of "dysbacteriosis" in broilers. Avian Pathol. 2011, 40, 139-144. [CrossRef]

6. Kohl, K.D. Diversity and function of the avian gut microbiota. J. Comp. Physiol. B 2012, 182, 591-602. [CrossRef]

7. Diaz Carrasco, J.M.; Casanova, N.A.; Fernández Miyakawa, M.E. Microbiota, gut health and chicken productivity: What is the connection? Microorganisms 2019, 7, 374. [CrossRef]

8. Corrigan, A.; de Leeuw, M.; Penaud-Frézet, S.; Dimova, D.; Murphy, R. Phylogenetic and functional alterations in bacterial community compositions in broiler ceca as a result of mannan oligosaccharide supplementation. Appl. Environ. Microbiol. 2015, 81, 3460-3470. [CrossRef]

9. Pan, D.; Yu, Z. Intestinal microbiome of poultry and its interaction with host and diet. Gut Microbes 2014, 5, 108-119. [CrossRef]

10. Gadde, U.; Kim, W.; Oh, S.; Lillehoj, H.S. Alternatives to antibiotics for maximizing growth performance and feed efficiency in poultry: A review. Anim. Health Res. Rev. 2017, 18, 26-45. [CrossRef]

11. Lillehoj, H.; Liu, Y.; Calsamiglia, S.; Fernandez-Miyakawa, M.E.; Chi, F.; Cravens, R.L.; Oh, S.; Gay, C.G. Phytochemicals as antibiotic alternatives to promote growth and enhance host health. Vet. Res. 2018, 49, 76. [CrossRef] [PubMed]

12. Yatao, X.; Saeed, M.; Kamboh, A.; Arain, M.; Ahmad, F.; Suheryani, I.; Abd El-Hack, M.; Alagawany, M.; Shah, Q.; Chao, S. The potentially beneficial effects of supplementation with hesperidin in poultry diets. Worlds Poult. Sci. J. 2018, 74, 265-276. [CrossRef]

13. Brenes, A.; Viveros, A.; Goni, I.; Centeno, C.; Sayago-Ayerdy, S.G.; Arija, I.; Saura-Calixto, F. Effect of grape pomace concentrate and vitamin $\mathrm{E}$ on digestibility of polyphenols and antioxidant activity in chickens. Poult. Sci. 2008, 87, 307-316. [CrossRef] [PubMed]

14. Awad, W.A.; Smorodchenko, A.; Hess, C.; Aschenbach, J.R.; Molnar, A.; Dublecz, K.; Khayal, B.; Pohl, E.E.; Hess, M. Increased intracellular calcium level and impaired nutrient absorption are important pathogenicity traits in the chicken intestinal epithelium during Campylobacter jejuni colonization. Appl. Microbiol. Biotechnol. 2015, 99, 6431-6441. [CrossRef] [PubMed]

15. Stanley, D.; Denman, S.E.; Hughes, R.J.; Geier, M.S.; Crowley, T.M.; Chen,H.; Haring, V.R.; Moore, R.J. Intestinal microbiota associated with differential feed conversion efficiency in chickens. Appl. Microbiol. Biotechnol. 2012, 96, 1361-1369. [CrossRef]

16. Shah, T.M.; Patel, J.G.; Gohil, T.P.; Blake, D.P.; Joshi, C.G. Host transcriptome and microbiome interaction modulates physiology of full-sibs broilers with divergent feed conversion ratio. NPJ Biofilms Microbiomes 2019, 5, 1-13. [CrossRef] [PubMed]

17. Han, G.G.; Kim, E.B.; Lee, J.; Lee, J.-Y.; Jin, G.; Park, J.; Huh, C.-S.; Kwon, I.-K.; Kil, D.Y.; Choi, Y.-J.; et al. Relationship between the microbiota in different sections of the gastrointestinal tract, and the body weight of broiler chickens. Springerplus 2016, 5, 911. [CrossRef] [PubMed] 
18. Rubio, L.A.; Peinado, M.J.; Ruiz, R.; Suarez-Pereira, E.; Ortiz Mellet, C.; Garcia Fernandez, J.M. Correlations between changes in intestinal microbiota composition and performance parameters in broiler chickens. J. Anim. Physiol. Anim. Nutr. 2015, 99, 418-423. [CrossRef] [PubMed]

19. Ocejo, M.; Oporto, B.; Hurtado, A. 16S rRNA amplicon sequencing characterization of caecal microbiome composition of broilers and free-range slow-growing chickens throughout their productive lifespan. Sci. Rep. 2019, 9, 2506. [CrossRef] [PubMed]

20. Metzler-Zebeli, B.U.; Siegerstetter, S.C.; Magowan, E.; Lawlor, P.G.; Petri, R.M.; NE, O.C.; Zebeli, Q. Feed Restriction Modifies Intestinal Microbiota-Host Mucosal Networking in Chickens Divergent in Residual Feed Intake. mSystems 2019, 4. [CrossRef] [PubMed]

21. Yan, W.; Sun, C.; Yuan, J.; Yang, N. Gut metagenomic analysis reveals prominent roles of Lactobacillus and cecal microbiota in chicken feed efficiency. Sci. Rep. 2017, 7, 45308. [CrossRef] [PubMed]

22. Singh, K.M.; Shah, T.; Deshpande, S.; Jakhesara, S.J.; Koringa, P.G.; Rank, D.N.; Joshi, C.G. High through put $16 \mathrm{~S}$ rRNA gene-based pyrosequencing analysis of the fecal microbiota of high FCR and low FCR broiler growers. Mol. Biol. Rep. 2012, 39, 10595-10602. [CrossRef] [PubMed]

23. Corrêa, T.A.F.; Rogero, M.M.; Hassimotto, N.M.A.; Lajolo, F.M. The Two-Way Polyphenols-Microbiota Interactions and Their Effects on Obesity and Related Metabolic Diseases. Front. Nutr. 2019, 6. [CrossRef] [PubMed]

24. Theilmann, M.C.; Goh, Y.J.; Nielsen, K.F.; Klaenhammer, T.R.; Barrangou, R.; Abou Hachem, M. Lactobacillus acidophilus metabolizes dietary plant glucosides and externalizes their bioactive phytochemicals. MBio 2017, 8. [CrossRef] [PubMed]

25. Viveros, A.; Chamorro, S.; Pizarro, M.; Arija, I.; Centeno, C.; Brenes, A. Effects of dietary polyphenol-rich grape products on intestinal microflora and gut morphology in broiler chicks. Poult. Sci. 2011, 90, 566-578. [CrossRef]

26. Espin, J.C.; Gonzalez-Sarrias, A.; Tomas-Barberan, F.A. The gut microbiota: A key factor in the therapeutic effects of (poly)phenols. Biochem. Pharmacol. 2017, 139, 82-93. [CrossRef]

27. Kawabata, K.; Yoshioka, Y.; Terao, J. Role of intestinal microbiota in the bioavailability and physiological functions of dietary polyphenols. Molecules 2019, 24, 370. [CrossRef]

28. Luca, S.V.; Macovei, I.; Bujor, A.; Miron, A.; Skalicka-Wozniak, K.; Aprotosoaie, A.C.; Trifan, A. Bioactivity of dietary polyphenols: The role of metabolites. Crit. Rev. Food Sci. Nutr. 2019, 1-34. [CrossRef]

29. Chamorro, S.; Romero, C.; Brenes, A.; Sánchez-Patán, F.; Bartolomé, B.; Viveros, A.; Arija, I. Impact of a sustained consumption of grape extract on digestion, gut microbial metabolism and intestinal barrier in broiler chickens. Food Funct. 2019, 10, 1444-1454. [CrossRef] [PubMed]

30. Siegerstetter, S.C.; Schmitz-Esser, S.; Magowan, E.; Wetzels, S.U.; Zebeli, Q.; Lawlor, P.G.; O'Connell, N.E.; Metzler-Zebeli, B.U. Intestinal microbiota profiles associated with low and high residual feed intake in chickens across two geographical locations. PLoS ONE 2017, 12, e0187766. [CrossRef] [PubMed]

31. Bae, Y.; Koo, B.; Lee, S.; Mo, J.; Oh, K.; Mo, I.P. Bacterial diversity and its relationship to growth performance of broilers. Korean J. Vet. Res. 2017, 57, 159-167.

32. Johnson, T.J.; Youmans, B.P.; Noll, S.; Cardona, C.; Evans, N.P.; Karnezos, T.P.; Ngunjiri, J.M.; Abundo, M.C.; Lee, C.-W. A consistent and predictable commercial broiler chicken bacterial microbiota in antibiotic-free production displays strong correlations with performance. Appl. Environ. Microbiol. 2018, 84, e00362-18. [CrossRef]

33. Torok, V.A.; Hughes, R.J.; Mikkelsen, L.L.; Perez-Maldonado, R.; Balding, K.; MacAlpine, R.; Percy, N.J.; Ophel-Keller, K. Identification and characterization of potential performance-related gut microbiotas in broiler chickens across various feeding trials. Appl. Environ. Microbiol. 2011, 77, 5868-5878. [CrossRef] [PubMed]

34. Siegerstetter, S.-C.; Petri, R.M.; Magowan, E.; Lawlor, P.G.; Zebeli, Q.; O'Connell, N.E.; Metzler-Zebeli, B.U. Feed restriction modulates the fecal microbiota composition, nutrient retention, and feed efficiency in chickens divergent in residual feed intake. Front. Microbiol. 2018, 9, 2698. [CrossRef] [PubMed]

35. Siegerstetter, S.-C.; Petri, R.M.; Magowan, E.; Lawlor, P.G.; Zebeli, Q.; O'Connell, N.E.; Metzler-Zebeli, B.U. Fecal microbiota transplant from highly feed-efficient donors shows little effect on age-related changes in feed-efficiency-associated fecal microbiota from chickens. Appl. Environ. Microbiol. 2018, 84, e02330-17. [CrossRef] 
36. Mosele, J.I.; Macià, A.; Motilva, M.-J. Metabolic and microbial modulation of the large intestine ecosystem by non-absorbed diet phenolic compounds: A review. Molecules 2015, 20, 17429-17468. [CrossRef]

37. Shimizu, M. Multifunctions of dietary polyphenols in the regulation of intestinal inflammation. J. Food Drug Anal. 2017, 25, 93-99. [CrossRef]

38. Surai, P. Polyphenol compounds in the chicken/animal diet: From the past to the future. J. Anim. Physiol. Anim. Nutr. 2014, 98, 19-31. [CrossRef]

39. Zhang, C.; Zhao, X.; Yang, L.; Chen, X.; Jiang, R.; Jin, S.; Geng, Z. Resveratrol alleviates heat stress-induced impairment of intestinal morphology, microflora, and barrier integrity in broilers. Poult. Sci. 2017, 96, 4325-4332. [CrossRef]

40. Khampeerathuch, T.; Mudsak, A.; Srikok, S.; Vannamahaxay, S.; Chotinun, S.; Chuammitri, P. Differential gene expression in heterophils isolated from commercial hybrid and Thai indigenous broiler chickens under quercetin supplementation. J. Appl. Anim. Res. 2018, 46, 804-812. [CrossRef]

41. Mattio, L.M.; Dallavalle, S.; Musso, L.; Filardi, R.; Franzetti, L.; Pellegrino, L.; D’Incecco, P.; Mora, D.; Pinto, A.; Arioli, S. Antimicrobial activity of resveratrol-derived monomers and dimers against foodborne pathogens. Sci. Rep. 2019, 9, 19525. [CrossRef] [PubMed]

42. Duda-Chodak, A.; Tarko, T.; Satora, P.; Sroka, P. Interaction of dietary compounds, especially polyphenols, with the intestinal microbiota: A review. Eur. J. Nutr. 2015, 54, 325-341. [CrossRef] [PubMed]

43. Marin, L.; Miguelez, E.M.; Villar, C.J.; Lombo, F. Bioavailability of dietary polyphenols and gut microbiota metabolism: Antimicrobial properties. BioMed Res. Int. 2015, 2015, 905215. [CrossRef] [PubMed]

44. Duenas, M.; Munoz-Gonzalez, I.; Cueva, C.; Jimenez-Giron, A.; Sanchez-Patan, F.; Santos-Buelga, C.; Moreno-Arribas, M.V.; Bartolome, B. A survey of modulation of gut microbiota by dietary polyphenols. BioMed Res. Int. 2015, 2015, 850902. [CrossRef] [PubMed]

45. Leusink, G.; Rempel, H.; Skura, B.; Berkyto, M.; White, W.; Yang, Y.; Rhee, J.Y.; Xuan, S.Y.; Chiu, S.; Silversides, F.; et al. Growth performance, meat quality, and gut microflora of broiler chickens fed with cranberry extract. Poult. Sci. 2010, 89, 1514-1523. [CrossRef]

46. Wang, C.; Yang, F.; Wang, Q.; Zhou, X.; Xie, M.; Kang, P.; Wang, Y.; Peng, X. Nutritive value of mulberry leaf meal and its effect on the performance of 35-70-day-old geese. J. Poult. Sci. 2016, 0160070. [CrossRef]

47. Shakeri, M.; Cottrell, J.J.; Wilkinson, S.; Le, H.H.; Suleria, H.A.; Warner, R.D.; Dunshea, F.R. Dietary Betaine Reduces the Negative Effects of Cyclic Heat Exposure on Growth Performance, Blood Gas Status and Meat Quality in Broiler Chickens. Agriculture 2020, 10, 176. [CrossRef]

48. Brenes, A.; Viveros, A.; Chamorro, S.; Arija, I. Use of polyphenol-rich grape by-products in monogastric nutrition. A review. Anim. Feed Sci. Technol. 2015, 211. [CrossRef]

49. Chen, Y.; Ni, J.; Li, H. Effect of green tea and mulberry leaf powders on the gut microbiota of chicken. BMC Vet. Res. 2019, 15, 77. [CrossRef]

50. Islam, M.R.; Lepp, D.; Godfrey, D.V.; Orban, S.; Ross, K.; Delaquis, P.; Diarra, M.S. Effects of wild blueberry (Vaccinium angustifolium) pomace feeding on gut microbiota and blood metabolites in free-range pastured broiler chickens. Poult. Sci. 2019, 98, 3739-3755. [CrossRef]

51. Das, Q.; Lepp, D.; Yin, X.; Ross, K.; McCallum, J.L.; Warriner, K.; Marcone, M.F.; Diarra, M.S. Transcriptional profiling of Salmonella enterica serovar Enteritidis exposed to ethanolic extract of organic cranberry pomace. PLoS ONE 2019, 14, e0219163. [CrossRef] [PubMed]

52. Das, Q.; Islam, M.; Lepp, D.; Tang, J.; Yin, X.; Mats, L.; Liu, H.; Ross, K.; Kennes, Y.M.; Yacini, H. Gut Microbiota, Blood Metabolites, and Spleen Immunity in Broiler Chickens Fed Berry Pomaces and Phenolic-Enriched Extractives. Front. Vet. Sci. 2020, 7. [CrossRef]

53. Hong, J.-C.; Steiner, T.; Aufy, A.; Lien, T.-F. Effects of supplemental essential oil on growth performance, lipid metabolites and immunity, intestinal characteristics, microbiota and carcass traits in broilers. Livest. Sci. 2012, 144, 253-262. [CrossRef]

54. Kamboh, A.A.; Zhu, W.Y. Individual and combined effects of genistein and hesperidin on immunity and intestinal morphometry in lipopolysacharide-challenged broiler chickens. Poult. Sci. 2014, 93, 2175-2183. [CrossRef] [PubMed]

55. Hajati, H.; Hassanabadi, A.; Golian, A.G.; Nassiri-Moghaddam, H.; Nassiri, M.R. The Effect of Grape Seed Extract and Vitamin C Feed Supplements Carcass Characteristics, Gut Morphology and Ileal Microflora in Broiler Chickens Exposed to Chronic Heat Stress. Iran. J. Appl. Anim. Sci. 2015, 5, 155-165. 
56. Samuel, K.; Wang, J.; Yue, H.; Wu, S.; Zhang, H.; Duan, Z.; Qi, G. Effects of dietary gallic acid supplementation on performance, antioxidant status, and jejunum intestinal morphology in broiler chicks. Poult. Sci. 2017, 96, 2768-2775. [CrossRef]

57. Liu, H.; Liu, Y.; Hu, L.; Suo, Y.; Zhang, L.; Jin, F.; Feng, X.; Teng, N.; Li, Y. Effects of dietary supplementation of quercetin on performance, egg quality, cecal microflora populations, and antioxidant status in laying hens. Poult. Sci. 2014, 93, 347-353. [CrossRef]

58. Czerwiński, J.; Śliżewska, K.; Korwin-Kossakowska, A.; Bachanek, I.; Smulikowska, S. Effects of genetically modified maize and soybean meal on the diversity and activity of gut microbiota in broiler chicken. Anim. Sci. Pap. Rep. 2017, 35, 279-299.

59. Panche, A.N.; Diwan, A.D.; Chandra, S.R. Flavonoids: An overview. J. Nutr. Sci. 2016, 5, e47. [CrossRef]

60. Iqbal, M.F.; Zhu, W.-Y. Bioactivation of flavonoid diglycosides by chicken cecal bacteria. FEMS Microbiol. Lett. 2009, 295, 30-41. [CrossRef]

61. Vaquero, M.R.; Alberto, M.R.; de Nadra, M.M. Antibacterial effect of phenolic compounds from different wines. Food Control 2007, 18, 93-101. [CrossRef]

62. Silván, J.M.; Mingo, E.; Hidalgo, M.; de Pascual-Teresa, S.; Carrascosa, A.V.; Martinez-Rodriguez, A.J. Antibacterial activity of a grape seed extract and its fractions against Campylobacter spp. Food Control 2013, 29, 25-31. [CrossRef]

63. Özkan, G.; Sagdiç, O.; Göktürk Baydar, N.; Kurumahmutoglu, Z. Antibacterial activities and total phenolic contents of grape pomace extracts. J. Sci. Food Agric. 2004, 84, 1807-1811. [CrossRef]

64. Kamboh, A.; Hang, S.-Q.; Khan, M.; Zhu, W.-Y. In vivo immunomodulatory effects of plant flavonoids in lipopolysaccharide-challenged broilers. Animal 2016, 10, 1619-1625. [CrossRef] [PubMed]

65. Zhang, X.; Zhao, L.; Cao, F.; Ahmad, H.; Wang, G.; Wang, T. Effects of feeding fermented Ginkgo biloba leaves on small intestinal morphology, absorption, and immunomodulation of early lipopolysaccharide-challenged chicks. Poult. Sci. 2013, 92, 119-130. [CrossRef]

66. Miller, M.J.; Angeles, F.M.; Reuter, B.K.; Bobrowski, P.; Sandoval, M. Dietary antioxidants protect gut epithelial cells from oxidant-induced apoptosis. BMC Complement. Altern. Med. 2001, 1, 11. [CrossRef]

67. Rechner, A.R.; Smith, M.A.; Kuhnle, G.; Gibson, G.R.; Debnam, E.S.; Srai, S.K.S.; Moore, K.P.; Rice-Evans, C.A. Colonic metabolism of dietary polyphenols: Influence of structure on microbial fermentation products. Free Radic. Biol. Med. 2004, 36, 212-225. [CrossRef]

68. Wang, S.; Yao, J.; Zhou, B.; Yang, J.; Chaudry, M.T.; Wang, M.; Xiao, F.; Li, Y.; Yin, W. Bacteriostatic effect of quercetin as an antibiotic alternative in vivo and its antibacterial mechanism in vitro. J. Food Prot. 2018, 81, 68-78. [CrossRef]

69. Kawabata, K.; Sugiyama, Y.; Sakano, T.; Ohigashi, H. Flavonols enhanced production of anti-inflammatory substance(s) by Bifidobacterium adolescentis: Prebiotic actions of galangin, quercetin, and fisetin. Biofactors 2013, 39, 422-429. [CrossRef]

70. Saitoh, S.; Sato, T.; Harada, H.; Matsuda, T. Biotransformation of soy isoflavone-glycosides in laying hens: Intestinal absorption and preferential accumulation into egg yolk of equol, a more estrogenic metabolite of daidzein. Biochim. Biophys. Acta 2004, 1674, 122-130. [CrossRef]

71. Hur, H.-G.; Beger, R.D.; Heinze, T.M.; Lay, J.O.; Freeman, J.P.; Dore, J.; Rafii, F.J. Isolation of an anaerobic intestinal bacterium capable of cleaving the C-ring of the isoflavonoid daidzein. Arch. Microbiol. 2002, 178, 8-12. [CrossRef] [PubMed]

72. Monagas, M.; Urpi-Sarda, M.; Sánchez-Patán, F.; Llorach, R.; Garrido, I.; Gómez-Cordovés, C.; Andres-Lacueva, C.; Bartolomé, B. Insights into the metabolism and microbial biotransformation of dietary flavan-3-ols and the bioactivity of their metabolites. Food Funct. 2010, 1, 233-253. [CrossRef] [PubMed]

73. Miladinović, B.; Kostić, M.; Šavikin, K.; Đorđević, B.; Mihajilov-Krstev, T.; Živanović, S.; Kitić, D. Chemical Profile and Antioxidative and Antimicrobial Activity of Juices and Extracts of 4 Black Currants Varieties (Ribes nigrum L.). J. Food Sci. 2014, 79, C301-C309. [CrossRef] [PubMed]

74. Chen, L.; Cao, H.; Xiao, J. Polyphenols: Absorption, bioavailability, and metabolomics. In Polyphenols: Properties, Recovery, and Applications; Elsevier Inc.: Cambridge, MA, USA, 2018; pp. 45-67.

75. Bakar, N.S.; Zin, N.M.; Basri, D.F. Synergy of flavone with vancomycin and oxacillin against vancomycin-intermediate Staphyloccus aureus. Pak. J. Pharm. Sci. 2012, 25, 633-638. [PubMed]

76. Bae, E.-A.; Han, M.J.; Kim, D.-H. In vitro anti-Helicobacter pylori activity of some flavonoids and their metabolites. Planta Med. 1999, 65, 442-443. [CrossRef] 
77. Agus, S.; Achmadi, S.S.; Mubarik, N.R. Antibacterial activity of naringenin-rich fraction of pigeon pea leaves toward Salmonella thypi. Asian Pac. J. Trop. Biomed. 2017, 7, 725-728. [CrossRef]

78. Goliomytis, M.; Kartsonas, N.; Charismiadou, M.A.; Symeon, G.K.; Simitzis, P.E.; Deligeorgis, S.G. The Influence of Naringin or Hesperidin Dietary Supplementation on Broiler Meat Quality and Oxidative Stability. PLoS ONE 2015, 10, e0141652. [CrossRef]

79. Simitzis, P.; Symeon, G.; Charismiadou, M.; Ayoutanti, A.; Deligeorgis, S. The effects of dietary hesperidin supplementation on broiler performance and chicken meat characteristics. Can. J. Anim. Sci. 2011, 91, 275-282. [CrossRef]

80. Setchell, K.D.; Clerici, C. Equol: History, chemistry, and formation. J. Nutr. 2010, 140, 1355S-1362S. [CrossRef]

81. Ulanowska, K.; Tkaczyk, A.; Konopa, G.; Węgrzyn, G. Differential antibacterial activity of genistein arising from global inhibition of DNA, RNA and protein synthesis in some bacterial strains. Arch. Microbiol. 2006, 184, 271-278. [CrossRef]

82. Verdrengh, M.; Collins, L.V.; Bergin, P.; Tarkowski, A. Phytoestrogen genistein as an anti-staphylococcal agent. Microbes Infect. 2004, 6, 86-92. [CrossRef] [PubMed]

83. Hervert-Hernandez, D.; Pintado, C.; Rotger, R.; Goni, I. Stimulatory role of grape pomace polyphenols on Lactobacillus acidophilus growth. Int. J. Food. Microbiol. 2009, 136, 119-122. [CrossRef] [PubMed]

84. Alakomi, H.-L.; Puupponen-Pimiä, R.; Aura, A.-M.; Helander, I.M.; Nohynek, L.; Oksman-Caldentey, K.-M.; Saarela, M. Weakening of Salmonella with selected microbial metabolites of berry-derived phenolic compounds and organic acids. J. Agric. Food Chem. 2007, 55, 3905-3912. [CrossRef] [PubMed]

85. Etxeberria, U.; Fernandez-Quintela, A.; Milagro, F.I.; Aguirre, L.; Martinez, J.A.; Portillo, M.P. Impact of polyphenols and polyphenol-rich dietary sources on gut microbiota composition. J. Agric. Food Chem. 2013, 61, 9517-9533. [CrossRef]

86. Duggan, C.; Gannon, J.; Walker, W.A. Protective nutrients and functional foods for the gastrointestinal tract. Am. J. Clin. Nutr. 2002, 75, 789-808. [CrossRef]

87. Cui, Y.; Oh, Y.; Lim, J.; Youn, M.; Lee, I.; Pak, H.; Park, W.; Jo, W.; Park, S. AFM study of the differential inhibitory effects of the green tea polyphenol (-)-epigallocatechin-3-gallate (EGCG) against Gram-positive and Gram-negative bacteria. Food Microbiol. 2012, 29, 80-87. [CrossRef]

88. Vance, S.H.; Tucci, M.; Benghuzzi, H. Evaluation of the antimicrobial efficacy of green tea extract (EGCG) against streptococcus pyogenes in vitro. Biomed. Sci. Instrum. 2011, 47, 177-182.

89. Sakanaka, S.; Juneja, L.R.; Taniguchi, M. Antimicrobial effects of green tea polyphenols on thermophilic spore-forming bacteria. J. Biosci. Bioeng. 2000, 90, 81-85. [CrossRef]

90. Yoda, Y.; Hu, Z.-Q.; Shimamura, T.; Zhao, W.-H. Different susceptibilities of Staphylococcus and Gram-negative rods to epigallocatechin gallate. J. Infect. Chemother. 2004, 10, 55-58. [CrossRef] [PubMed]

91. Lee, K.-M.; Kim, W.-S.; Lim, J.; Nam, S.; Youn, M.; Nam, S.-W.; Kim, Y.; Kim, S.-H.; Park, W.; Park, S. Antipathogenic properties of green tea polyphenol epigallocatechin gallate at concentrations below the MIC against enterohemorrhagic Escherichia coli O157: H7. J. Food Prot. 2009, 72, 325-331. [CrossRef] [PubMed]

92. Prior, R.L.; Wu, X. Anthocyanins: Structural characteristics that result in unique metabolic patterns and biological activities. Free. Radic. Res. 2006, 40, 1014-1028. [CrossRef] [PubMed]

93. Keppler, K.; Humpf, H.-U. Metabolism of anthocyanins and their phenolic degradation products by the intestinal microflora. Bioorg. Med. Chem. 2005, 13, 5195-5205. [CrossRef] [PubMed]

94. Ávila, M.; Hidalgo, M.; Sánchez-Moreno, C.; Pelaez, C.; Requena, T.; de Pascual-Teresa, S. Bioconversion of anthocyanin glycosides by Bifidobacteria and Lactobacillus. Food Res. Int. 2009, 42, 1453-1461. [CrossRef]

95. Changxing, L.; Chenling, M.; Alagawany, M.; Jianhua, L.; Dongfang, D.; Gaichao, W.; Wenyin, Z.; Syed, S.; Arain, M.; Saeed, M. Health benefits and potential applications of anthocyanins in poultry feed industry. Worlds Poult. Sci. J. 2018, 74, 251-264. [CrossRef]

96. Ouyang, K.; Xiong, X.; Wang, W.; Hu, Y.; Zhou, P.; Liu, D. Effects of alfalfa flavones on growth performance and carcass quality of female Chongren chickens. Acta Pratacult. Sin. 2013, 22, 340-345.

97. Eumkeb, G.; Siriwong, S.; Thumanu, K. Synergistic activity of luteolin and amoxicillin combination against amoxicillin-resistant Escherichia coli and mode of action. J. Photochem. Photobiol. B Biol. 2012, 117, $247-253$. [CrossRef]

98. Abd-Alla, H.I.; Abu-Gabal, N.S.; Hassan, A.Z.; El-Safty, M.M.; Shalaby, N.M. Antiviral activity of Aloe hijazensis against some haemagglutinating viruses infection and its phytoconstituents. Arch. Pharmacal Res. 2012, 35, 1347-1354. [CrossRef] 
99. Kumarasamy, Y.; Nahar, L.; Byres, M.; Delazar, A.; Sarker, S.D. The assessment of biological activities associated with the major constituents of the methanol extract of 'wild carrot' (Daucus carota L.) seeds. J. Herb. Pharmacother. 2005, 5, 61-72.

100. Brglez Mojzer, E.; Knez Hrnčič, M.; Škerget, M.; Knez, Ž.; Bren, U. Polyphenols: Extraction methods, antioxidative action, bioavailability and anticarcinogenic effects. Molecules 2016, 21, 901. [CrossRef]

101. Aura, A.-M. In Vitro Digestion Models for Dietary Phenolic Compounds; VTT Technical Research Centre of Finland: Espoo, Finland, 2005.

102. Raimondi, S.; Anighoro, A.; Quartieri, A.; Amaretti, A.; Tomás-Barberán, F.A.; Rastelli, G.; Rossi, M. Role of bifidobacteria in the hydrolysis of chlorogenic acid. MicrobiologyOpen 2015, 4, 41-52. [CrossRef]

103. Cueva, C.; Moreno-Arribas, M.V.; Martín-Álvarez, P.J.; Bills, G.; Vicente, M.F.; Basilio, A.; Rivas, C.L.; Requena, T.; Rodríguez, J.M.; Bartolomé, B. Antimicrobial activity of phenolic acids against commensal, probiotic and pathogenic bacteria. Res. Microbiol. 2010, 161, 372-382. [CrossRef] [PubMed]

104. Lee, J.H.; Shim, J.S.; Lee, J.S.; Kim, J.K.; Yang, I.S.; Chung, M.S.; Kim, K.H. Inhibition of pathogenic bacterial adhesion by acidic polysaccharide from green tea (Camellia sinensis). J. Agric. Food Chem. 2006, 54, 8717-8723. [CrossRef] [PubMed]

105. Borges, A.; Saavedra, M.J.; Simões, M. The activity of ferulic and gallic acids in biofilm prevention and control of pathogenic bacteria. Biofouling 2012, 28, 755-767. [CrossRef] [PubMed]

106. Govardhan Singh, R.S.; Negi, P.S.; Radha, C. Phenolic composition, antioxidant and antimicrobial activities of free and bound phenolic extracts of Moringa oleifera seed flour. J. Funct. Foods 2013, 5, 1883-1891. [CrossRef]

107. Rowland, I.; Gibson, G.; Heinken, A.; Scott, K.; Swann, J.; Thiele, I.; Tuohy, K. Gut microbiota functions: Metabolism of nutrients and other food components. Eur. J. Nutr. 2018, 57, 1-24. [CrossRef]

108. Diaz Carrasco, J.M.; Redondo, E.A.; Pin Viso, N.D.; Redondo, L.M.; Farber, M.D.; Fernandez Miyakawa, M.E. Tannins and bacitracin differentially modulate gut microbiota of broiler chickens. BioMed Res. Int. 2018, 2018, 1879168. [CrossRef]

109. Mattioli, S.; Ruggeri, S.; Sebastiani, B.; Brecchia, G.; Dal Bosco, A.; Cartoni Mancinelli, A.; Castellini, C. Performance and egg quality of laying hens fed flaxseed: Highlights on n-3 fatty acids, cholesterol, lignans and isoflavones. Animal 2017, 11, 705-712. [CrossRef]

110. Tomás-Barberán, F.A.; González-Sarrías, A.; García-Villalba, R.; Núñez-Sánchez, M.A.; Selma, M.V.; García-Conesa, M.T.; Espín, J.C. Urolithins, the rescue of "old" metabolites to understand a "new" concept: Metabotypes as a nexus among phenolic metabolism, microbiota dysbiosis, and host health status. Mol. Nutr. Food Res. 2017, 61, 1500901. [CrossRef]

111. Shanmugam, M.; Rao, S.R. Effect of dietary ellagic acid supplementation on semen quality parameters in chickens. Anim. Prod. Sci. 2015, 55, 107-112. [CrossRef]

112. Kumar, S.; Chen, C.; Indugu, N.; Werlang, G.O.; Singh, M.; Kim, W.K.; Thippareddi, H. Effect of antibiotic withdrawal in feed on chicken gut microbial dynamics, immunity, growth performance and prevalence of foodborne pathogens. PLoS ONE 2018, 13, e0192450. [CrossRef]

113. Yilmaz, B.; Li, H. Gut microbiota and iron: The crucial actors in health and disease. Pharmaceuticals 2018, 11, 98. [CrossRef] [PubMed]

114. Redondo, L.; Chacana, P.; Dominguez, J.; Fernandez Miyakawa, M. Perspectives in the use of tannins as alternative to antimicrobial growth promoter factors in poultry. Front. Microbiol. 2014, 5. [CrossRef] [PubMed]

115. Masek, T.; Starcevic, K.; Filipovic, N.; Stojevic, Z.; Brozic, D.; Gottstein, Z.; Severin, K. Tissue fatty acid composition and estimated desaturase activity after castration in chicken broilers fed with linseed or sunflower oil. J. Anim. Physiol. Anim. Nutr. 2014, 98, 384-392. [CrossRef] [PubMed]

116. Sell, D.; Reed, W.; Chrisman, C.; Rogler, J. Mucin excretion and morphology of the intestinal tract as influenced by sorghum tannins. Nutr. Rep. Int. 1985, 31, 1369-1374.

117. Ortiz, L.; Alzueta, C.; Trevino, J.; Castano, M. Effects of faba bean tannins on the growth and histological structure of the intestinal tract and liver of chicks and rats. Br. Poult. Sci. 1994, 35, 743-754. [CrossRef] [PubMed]

118. Possemiers, S.; Bolca, S.; Eeckhaut, E.; Depypere, H.; Verstraete, W. Metabolism of isoflavones, lignans and prenylflavonoids by intestinal bacteria: Producer phenotyping and relation with intestinal community. FEMS Microbiol. Ecol. 2007, 61, 372-383. [CrossRef] 
119. Quartieri, A.; García-Villalba, R.; Amaretti, A.; Raimondi, S.; Leonardi, A.; Rossi, M.; Tomàs-Barberàn, F. Detection of novel metabolites of flaxseed lignans in vitro and in vivo. Mol. Nutr. Food Res. 2016, 60, 1590-1601. [CrossRef]

120. Chaplin, A.; Carpéné, C.; Mercader, J. Resveratrol, metabolic syndrome, and gut microbiota. Nutrients 2018, 10, 1651. [CrossRef]

121. Bird, J.K.; Raederstorff, D.; Weber, P.; Steinert, R.E. Cardiovascular and antiobesity effects of resveratrol mediated through the gut microbiota. Adv. Nutr. 2017, 8, 839-849. [CrossRef]

122. Mohebodini, H.; Jazi, V.; Bakhshalinejad, R.; Shabani, A.; Ashayerizadeh, A. Effect of dietary resveratrol supplementation on growth performance, immune response, serum biochemical indices, cecal microflora, and intestinal morphology of broiler chickens challenged with Escherichia coli. Livest. Sci. 2019, 229, $13-21$. [CrossRef]

(C) 2020 by the authors. Licensee MDPI, Basel, Switzerland. This article is an open access article distributed under the terms and conditions of the Creative Commons Attribution (CC BY) license (http://creativecommons.org/licenses/by/4.0/). 